\title{
Abiotic factors affecting the development of Ulva sp. (Ulvophyceae; Chlorophyta) in freshwater ecosystems
}

\author{
Beata Messyasz • Andrzej Rybak
}

Received: 26 January 2010/ Accepted: 7 July 2010/Published online: 20 July 2010

(C) The Author(s) 2010. This article is published with open access at Springerlink.com

\begin{abstract}
The influence of physicochemical factors on the development of Ulva species with distromatic tubular morphology was studied in three streams located in Poznan, Poland. The study evaluated key environmental factors that may influence the colonisation and growth of Ulva populations in freshwater systems. In total, nine environmental parameters were included: temperature, water depth, $\mathrm{pH}$, oxygen $\left(\mathrm{O}_{2}\right)$, ammonium $\left(\mathrm{NH}_{4}{ }^{+}\right)$, nitrate $\left(\mathrm{NO}_{3}{ }^{-}\right)$, phosphate $\left(\mathrm{PO}_{4}{ }^{3-}\right)$, sodium chloride $(\mathrm{NaCl})$ and total iron (Fe). Morphometric features of thalli (length and width, percentage of furcated and young thalli) and surface area of free-floating mats formed by the freshwater populations of Ulva were compared at all sites. Principal components analysis indicated the most important factors influencing Ulva development were sodium chloride concentrations and water depth. Two other key chemical factors affecting the freshwater form of Ulva were phosphate and nitrite concentrations. High concentrations of sodium chloride inhibited the development of Ulva, leading to a lower number of thalli in the Ulva mats. At the sites
\end{abstract}

Handling editor: Piet Spaak.

B. Messyasz $(\bowtie) \cdot$ A. Rybak

Department of Hydrobiology, Institute of Environmental Biology, Faculty of Biology, Adam Mickiewicz University, Umultowska Str. 89, 61-614 Poznan, Poland e-mail: messyasz@amu.edu.pl with stable and deeper water, the surface area of the mats was larger. Both phosphate and nitrite concentrations were positively correlated with an increase in the number of thalli in the mats and the thalli length.

Keywords Ulva $\cdot$ Chlorophyta $\cdot$ Macroalgae mats . PCA $\cdot$ Ecology $\cdot$ Nutrients

\section{Introduction}

The cosmopolitan genus Ulva (Fish and Fish 1989; Fletcher 1996; Callow et al. 1997; Bäck et al. 2000; Gabrielson et al. 2000; Graham and Wilcox 2000; Blomster et al. 2002; Hayden et al. 2003; Leskinen et al. 2004) is mostly found in marine and brackish waters (Kirchhoff and Pflugmacher 2002; Lee 1999; Romano et al. 2003) and estuaries (Bäck et al. 2000; McAvoy and Klug 2005). It can also be present in freshwaters, often in ecosystems located far inland on continents and islands that are not in contact with salt waters. During the 20th century, such freshwater Ulva populations have been recorded in eight countries, including Great Britain (Whitton and Dalpra 1968), the United States (Taft 1964; Reinke 1981), the Czech Republic (Mareš 2009), Japan (Ichihara et al. 2009), Pakistan (Leghari et al. 2000), New Zealand (Williams 1993) and Poland (Messyasz and Rybak 2009).

Thirteen species of Ulva have been reported from the Polish Baltic coastline (Pliński et al. 1982; Pliński 
and Florczyk 1984). Typically, marine Ulva species have also been observed in several freshwater systems in Poland (Göppert and Cohn 1850; Kozłowski 1890; Raciborski 1910; Wysocka 1952; Piotrowska 1961; Pliński 1971; Sitkowska 1999; Messyasz and Rybak 2009). Between 1849 and 2007, five species and one subspecies of Ulva were observed at 58 inland sites in Poland (Messyasz and Rybak 2009). These occurred as either single or large concentrations of thalli in various freshwater ecosystems, mostly lakes, but also in small rivers, streams and ponds. Other sites included peat pits, clay pits and stream basins. The most common species at these inland Polish sites included Ulva intestinalis (34 sites), U. flexuosa (10 sites), U. prolifera (5 sites) and U. compressa (4 sites). Also, the rarest Ulva species in Polish freshwaters, U. paradoxa, has been observed at only 2 sites, while the subspecies $U$. flexuosa subsp. pilifera has been seen at 3 locations.

Young Ulva have a thallus that remains either attached to a substrate or they can develop unattached, as drifting individuals or as aggregations of free-floating mats (Bliding 1963, 1968; Starmach 1972). Freshwater forms of Ulva appear only as monostromatic tubular thalli (e.g. Ulva intestinalis and Ulva compressa). So far, Ulva with distromatic frondose thalli has not been reported in freshwater ecosystems (Messyasz and Rybak 2009). Mature plants of freshwater Ulva can have one of the two types of thalli surface architecture. One has an intestinally undulating thallus with a smooth surface, and the other is curly bubbled with a strongly corrugated and often highly furcated thallus (Marczek 1954). It has been frequently observed that a few Ulva species form freely floating thallus mats (Fletcher 1996; Callow et al. 1997; Blomster et al. 2002). Their appearance in a marine littoral zone has been related to the nutrient enrichment of littoral waters (Wallentinus 1979; Sfriso and Marconimi 1997; Raffaelli et al. 1989; Martins et al. 2001; Żbikowski et al. 2005).

This paper's objective is to provide additional information to previous ecological studies of freshwater Ulva populations in Poland. Detailed ecological studies of parameters that influence the occurrence of Ulva species in freshwaters need to be investigated. Therefore, the goal of this work was to determine the influence of the colonisation and growth of Ulva populations in freshwater ecosystems using examples from three streams in Poland. An additional concern was to evaluate the impact on Ulva species in freshwater ecosystems, associated with anthropogenic sodium chloride pollution and nutrient ( $\mathrm{N}$ and $\mathrm{P}$ ) enrichment.

\section{Materials and methods}

\section{Study area}

The study sites containing Ulva were located in three $\sim 0.5-\mathrm{m}$ deep steams in the south-eastern area of Poznań, Poland (Fig. 1). Two sites containing Ulva were in the Michałówka stream $\left(52^{\circ} 20^{\prime} 20^{\prime \prime} \mathrm{N}\right.$, $17^{\circ} 02^{\prime} 44^{\prime \prime} \mathrm{E}$ and $\left.52^{\circ} 20^{\prime} 21^{\prime \prime} \mathrm{N}, 17^{\circ} 02^{\prime} 45^{\prime \prime} \mathrm{E}\right)$ and one in the Dworski Rów stream $\left(52^{\circ} 21^{\prime} 28^{\prime \prime} \mathrm{N}, 17^{\circ} 02^{\prime} 30^{\prime \prime} \mathrm{E}\right)$. The sites in Michałówka and Dworski Rów were located $541 \mathrm{~m}$ from each other. Another location containing these macroalgae was in the Światnica stream $\left(52^{\circ} 21^{\prime} 39^{\prime \prime} \mathrm{N}, 17^{\circ} 02^{\prime} 42^{\prime \prime} \mathrm{E}\right)$, which is $4.5 \mathrm{~km}$ from the other two sites. All sites containing Ulva were in the vicinity of a motorway. The Michałówka sites (hereinafter "M1" and "M2") were $34 \mathrm{~m}$ and $19 \mathrm{~m}$ from the motorway, respectively. The third site in Dworski Rów (hereinafter "DR") was $425 \mathrm{~m}$ from the motorway, and the fourth one in Świątnica (hereinafter "S") was located $246 \mathrm{~m}$ from the motorway.

\section{Chemical analysis}

The physicochemical parameters of waters from the four sites containing Ulva were analysed when the macroalgae thalli were present, i.e., from August until October, 2007. Water temperature, $\mathrm{pH}$ and oxygen levels were measured using Elmetron CX-401 and CPC-501 protocols with this analysis, repeated weekly. Additionally, changes in water depth, thickness of bottom sediments and shading of the sites by vascular plants (immersed and floating) were monitored. Water samples $(500 \mathrm{~mL})$ were collected for chemical analyses and preserved with $0.5 \mathrm{ml}$ of chloroform. These samples were then stored in refrigerators at $4{ }^{\circ} \mathrm{C}$, with chemical analyses performed using standard methods for a Hach DR 2010 spectrophotometer. Concentrations were determined for the following variables: ammonium, nitrate, phosphate, sodium chloride and iron. 
Fig. 1 Location of the sampling sites of freshwater Ulva populations in the Wielkopolska region (Central Europe, Poland, Poznan City). 1 motorway, 2 streams, 3 water channels, 4 roads, 5 railway, 6 forests, 7 built-up areas, 8 meadows
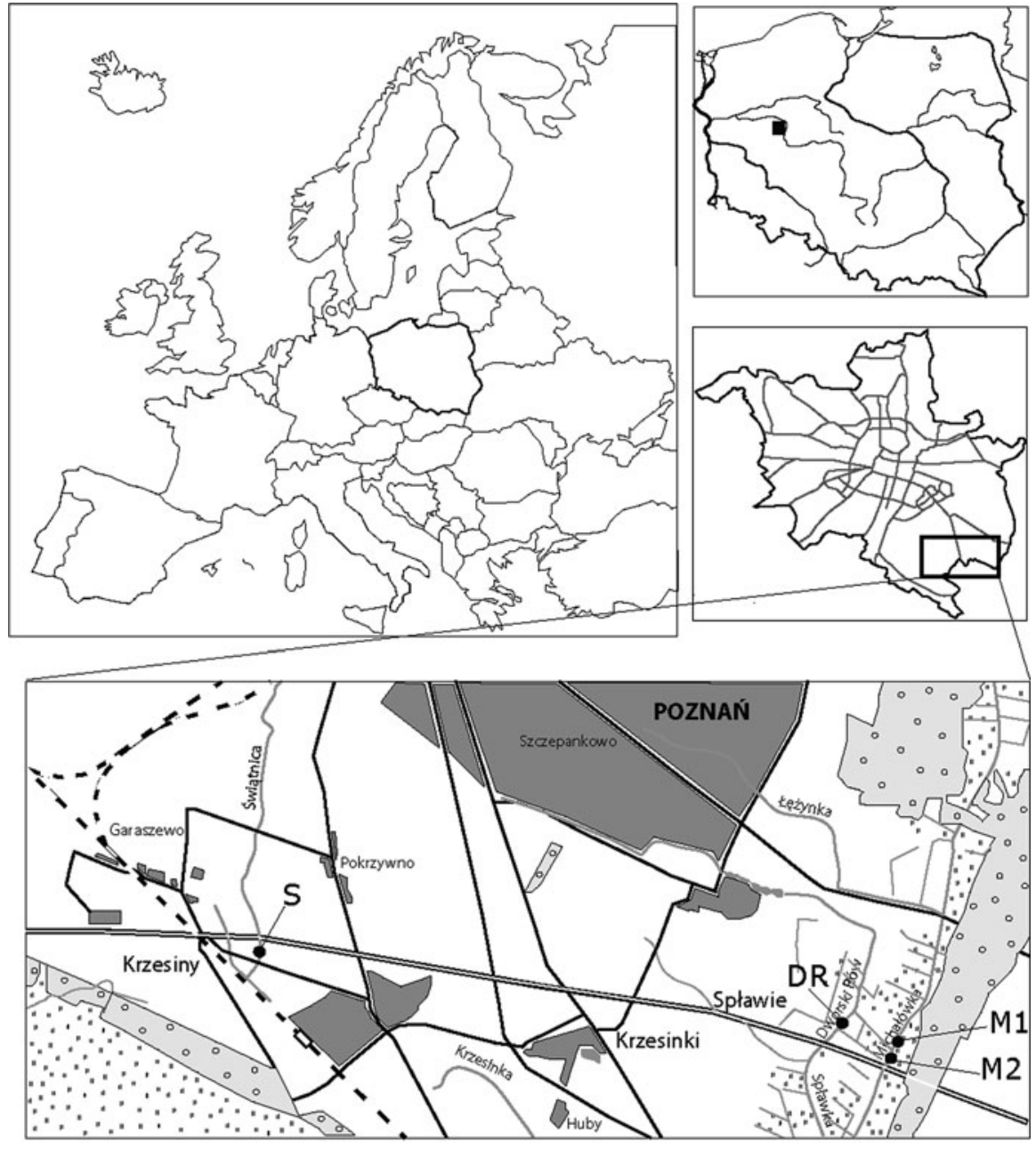

$1000 \mathrm{~m} \quad \underbrace{\mathrm{km}} \quad \mathrm{S}, \mathrm{DR}, \mathrm{M1}, \mathrm{M2}$ - localities of Ulva

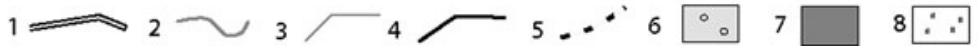

Both the percentage of water surface area covered by Ulva thalli and the density of Ulva thalli per $\mathrm{m}^{-2}$ of surface water were evaluated in the field. The lengths and widths of thalli taken from each site were also measured. The morphometrical measurements were repeated ex situ on material preserved with formalin (4\% concentration). Macroalgae mats were analysed to determine the number of furcated thalli and the presence of young and mature plants.

Statistical analysis

STATISTICA 7.0 and CANOCO 6.2. software were used for the statistical analysis of the collected data. The correlation between physicochemical parameters and morphometric features of thalli defined using Pearson's linear correlation coefficient including $r^{2}$ ratio. A PCA (principal components analysis) method was used to compare the diversity of physicochemical environmental parameters and then to determine relationships to the Ulva populations.

\section{Results}

Physicochemical profiles of the study sites

During the study period (July-October 2007), water temperature and $\mathrm{pH}$ values were similar for all sites. The highest water temperature was at $S$ because of 
Table 1 Average values of physicochemical factors of water for the examined sites

\begin{tabular}{llcrrr}
\hline Parameter & Units & \multicolumn{1}{c}{$M_{1}$} & \multicolumn{1}{c}{$M_{2}$} & DR & \multicolumn{1}{c}{$S$} \\
\hline Temperature & $\left({ }^{\circ} \mathrm{C}\right)$ & $14.77(2.56)$ & $15.09(2.68)$ & $14.75(2.73)$ & $15.72(2.48)$ \\
$\mathrm{pH}$ & - & $8.16(0.67)$ & $8.11(0.64)$ & $8.04(0.52)$ & $7.97(0.70)$ \\
Depth of water & $(\mathrm{cm})$ & $50.12(19.36)$ & $44.00(22.76)$ & $48.68(9.60)$ & $16.25(3.07)$ \\
$\mathrm{O}_{2}$ & $\left(\mathrm{mg} \mathrm{L}^{-1}\right)$ & $2.26(1.29)$ & $2.12(1.47)$ & $0.52(0.20)$ & $4.00(0.78)$ \\
$\mathrm{N}^{-\mathrm{NH}_{4}}{ }^{+}$ & $\left(\mathrm{mg} \mathrm{L}^{-1}\right)$ & $1.34(1.19)$ & $1.44(1.18)$ & $0.90(0.82)$ & $0.31(0.58)$ \\
$\mathrm{N}^{-} \mathrm{NO}_{3}{ }^{-}$ & $\left(\mathrm{mg} \mathrm{L}^{-1}\right)$ & $0.64(0.36)$ & $0.70(0.37)$ & $0.40(0.35)$ & $0.05(0.02)$ \\
$\mathrm{P}_{-} \mathrm{PO}_{4}{ }^{-}$ & $\left(\mathrm{mg} \mathrm{L}^{-1}\right)$ & $0.71(0.15)$ & $0.74(0.19)$ & $0.19(0.11)$ & $0.02(0.01)$ \\
$\mathrm{NaCl}$ & $\left(\mathrm{mg} \mathrm{L}^{-1}\right)$ & $544.97(38.33)$ & $549.25(26.77)$ & $651.35(81.30)$ & $697.51(78.87)$ \\
Total Fe & $\left(\mathrm{mg} \mathrm{L}^{-1}\right)$ & $0.29(0.24)$ & $0.31(0.18)$ & $1.18(0.62)$ & $0.04(0.03)$ \\
\hline
\end{tabular}

Data are means (SD); $n=30 ; M_{1}, M_{2}$, DR and $S$-sites

the shallow water level of the watercourse (average temperature of $15.72^{\circ} \mathrm{C}$ at an average depth of $16.25 \mathrm{~cm}$ ). Measurements of $\mathrm{pH}$ for all four sites were approximately 8.0 (Table 1).

The lowest oxygen concentrations were at DR $\left(0.52 \mathrm{mg} \mathrm{L}^{-1}\right)$, and at the other three sites, where the waters could mix as they flowed, with a more open surface area, the oxygen levels were higher. The highest oxygen concentrations $\left(4.0 \mathrm{mg} \mathrm{L}^{-1}\right)$ were at $S$ where there was a strong current flow in the stream.

$\mathrm{M}_{1}$ and $M_{2}$ had higher concentrations of phosphates in comparison with the other water courses. The lowest values of $\mathrm{P}_{-} \mathrm{PO}_{4}$ were at $S\left(0.01 \mathrm{mg} \mathrm{L}{ }^{-1}\right)$. The opposite situation occurred for sodium chloride content in the other streams, where the lowest concentrations were observed for both $M$ sites $\left(M_{1}-544.97\right.$ and $\left.M_{2}-549.25 \mathrm{mg} \mathrm{L}^{-1}\right)$. A higher salt level was measured at DR $\left(651.35 \mathrm{mg} \mathrm{L}^{-1}\right)$, and the highest was found at $S\left(697.51 \mathrm{mg} \mathrm{L}^{-1}\right)$.

Higher levels of ammonium nitrogen were also at $M_{1}-1.34 \mathrm{mg} \mathrm{L}^{-1}, M_{2}-1.44 \mathrm{mg} \mathrm{L}^{-1}$ and $\mathrm{DR}-0.90$ $\mathrm{mg} \mathrm{L}^{-1}$ in comparison with $S\left(0.06 \mathrm{mg} \mathrm{L}^{-1}\right)$. A similar situation was observed for nitrite content in the waters from the M1, M2 and DR, with the nitrite level much higher $\left(M_{1}-0.64 ; M_{2}-0.70 ; \mathrm{DR}-\right.$ $0.40 \mathrm{mg} \mathrm{L}^{-1}$ ), while in the $S$ site the concentration was only $0.05 \mathrm{mg} \mathrm{L}^{-1}$ (Table 1).

Waters from DR had the highest concentrations of total iron, at $1.18 \mathrm{mg} \mathrm{L}^{-1}$ compared to the other sites $\left(M_{1}-0.29 ; M_{2}-0.31 ; S-0.01 \mathrm{mg} \mathrm{L}^{-1}\right)$.

Both $M_{1}$ and $M_{2}$ were very similar in regard to most physicochemical factors, i.e., water depth, concentration of oxygen, phosphate, nitrate, sodium chloride, ammonium nitrogen and iron.
Similar values in the results of these sites may be associated with their close proximity to each other in Michałówka stream.

\section{Phenology of Ulva}

From August 5 until October 2, 2007, characteristics of Ulva thalli were examined and recorded from the three streams. During this period, the number of thalli at a given site, and consequently the mats formed by this species, underwent changes that were monitored. In July and in early August at each of the Ulva monitoring locations, filamentous algae of the genera Cladophora sp. and Oedogonium sp. were the dominant flora in the surface water. However, the abundance of these species declined in mid-August when the concentration of Ulva thalli significantly increased. During this period, the Ulva mats covered $60-90 \%$ of the stream's width, and Ulva became the dominant species of the surface water layer. Also, the filamentous algae were observed at the bottom of the $M_{1}$ and DR stations. At the end of August, after the developmental optimum of Ulva, it was evident that there was an intensive growth of vascular plants that were freely floating on the water's surface at all sites containing macroalgae. Lemna gibba, Lemna minor and occasionally Spirodela polyrrhiza began to gradually displace Ulva from the water's surface in each of the streams. After August 20, a complex of these pleustophytes species covered the entire water surface at M1, M2 and DR. Domination by duckweed and Spirodela was not observed in Świątnica due to the rapid water flow in this stream. 
Morphometric characteristics of Ulva

Ulva thalli growing in the streams formed floating mats (macroalgae scum). However, each mat for a given site had a characteristic number of thalli, structure and surface density in the water column. The largest Ulva mats exceeded $\sim 2 \mathrm{~m}^{2}$ and appeared at $M_{1}$ and $M_{2}$ (Table 2).

Both $M_{1}$ and $M_{2}$ contained abundant Ulva thalli, which always formed one larger and denser mat and a few smaller ones with a loose structure, located near stream banks. At the end of August, the mat's surface area was the largest at $M_{1}$ measuring about $4 \mathrm{~m}^{2}$. In the same period at $M_{2}$, the macroalgae mat was ca. $2 \mathrm{~m}^{2}$. At DR, the mats were smaller, their surface area rarely exceeded $1 \mathrm{~m}^{2}$ and their structure was not dense. The smallest mats were recorded at $S$, with the surface covering only $0.10-0.30 \mathrm{~m}^{2}$.

The thalli density in the mats was different for every site. For the $M_{1}$ and $M_{2}$, thalli densities were $\sim 52 \mathrm{~m}^{-2}$ and $\sim 44 \mathrm{~m}^{-2}$, respectively. In Świątnica and Dworski Rów, the lowest thalli densities were recorded at DR and $S$ of $\sim 6 \mathrm{~m}^{-2}$ and $\sim 2 \mathrm{~m}^{-2}$, respectively. The longest and widest thalli occurred at $M_{1}$ (average length- $14.15 \mathrm{~cm}$, average width$0.82 \mathrm{~cm}$ ) and $M_{2}$ (average length $-12.42 \mathrm{~cm}$, average width $-0.89 \mathrm{~cm}$ ). The thalli of Ulva from DR and $S$ were shorter and narrower than those from Michałówka (Table 2). Furcated and non-furcated thalli surface architecture was recorded at all sites. At $M_{1}$ and $S$, the percentage of the furcated thalli density mat was over $40 \%$, and at the other sites it was $>20 \%$. In every mat from a given stream, mature thalli constituted more than $60 \%$ of the mat. The percentage of mature thalli in mats was highest in Świątnica, where it exceeded $90 \%$.

Effect of water chemistry on Ulva development

In this study, the most important factors affecting morphological development of Ulva were depth and sodium chloride concentration (Fig. 2). These parameters explained 83 and $88 \%$, respectively, of the variability in the data obtained from the studied sites.

Table 2 Average values of morphometric thalli features and Ulva mats

\begin{tabular}{llllll}
\hline Parameters & Units & $M_{1}$ & $M_{2}$ & DR & $S$ \\
\hline Surface of the mats & $\left(\mathrm{m}^{2}\right)$ & $1.84(1.36)$ & $1.17(0.63)$ & $0.51(0.17)$ & $0.15(0.08)$ \\
Density of thalli in $\mathrm{m}^{-2}$ of the mats & $\left(\mathrm{m}^{-2}\right)$ & $52.88(25.68)$ & $44.71(9.88)$ & $6.33(1.75)$ & $2.83(1.17)$ \\
Average length of the thallus & $(\mathrm{cm})$ & $14.15(3.83)$ & $12.42(2.58)$ & $6.63(2.16)$ & $7.14(1.86)$ \\
Average width of the thallus & $(\mathrm{cm})$ & $0.82(0.47)$ & $0.89(0.48)$ & $5.53(0.14)$ & $0.61(0.25)$ \\
The percentage of the branched thallus in $\mathrm{m}^{-2}$ of the mats & $(\%)$ & $41.67(23.37)$ & $20.71(32.46)$ & $26.67(27.87)$ & $41.65(35.87)$ \\
The percentage of the unbranched thallus in $\mathrm{m}^{-2}$ of the mats & $(\%)$ & $58.33(23.32)$ & $79.28(32.46)$ & $73(27.87)$ & $85.33(35.87)$ \\
The percentage of the young thallus in $\mathrm{m}^{-2}$ of the mats & $(\%)$ & $37.78(37.76)$ & $15.71(18.13)$ & $25.83(34.70)$ & $5.83(3.76)$ \\
The percentage of the mature thallus in $\mathrm{m}^{-2}$ of the mats & $(\%)$ & $62.22(37.66)$ & $84.28(18.13)$ & $74.17(34.70)$ & $94.17(3.76)$ \\
\hline
\end{tabular}

Data are means, (SD), $n=30, M_{1}, M_{2}, \mathrm{DR}$ and $S$-sites

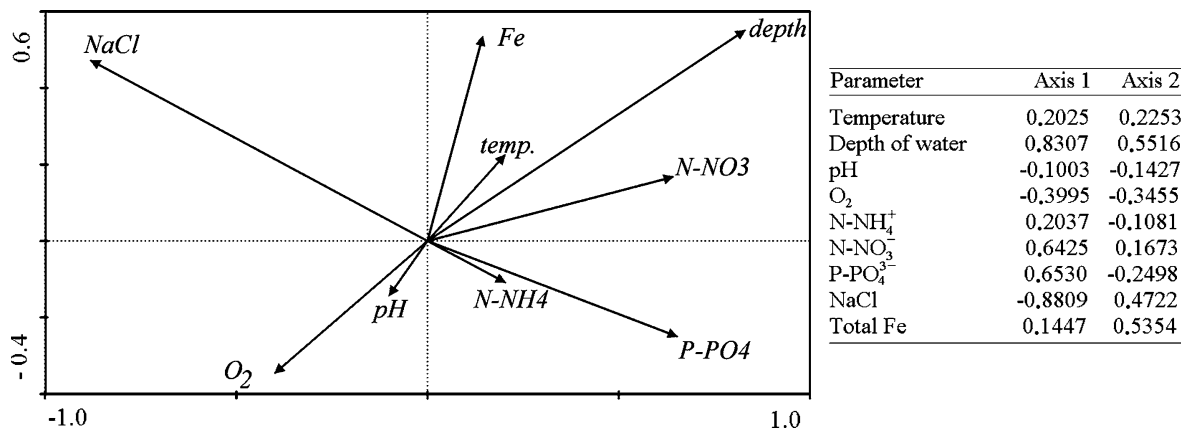

Fig. 2 The PCA diagram for individual physicochemical factors of water from four freshwater Ulva sites 


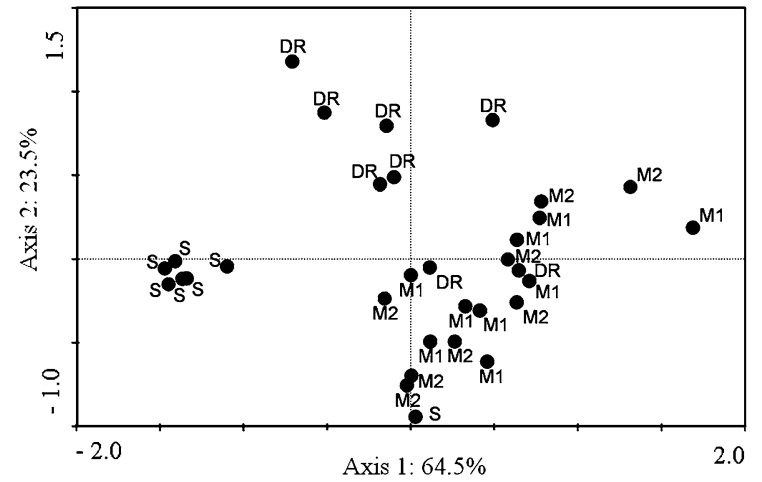

Fig. 3 Results of PCA grouping at all sites on the basis of water physicochemical factors $\left(M_{1}, M_{2}, \mathrm{DR}\right.$ and $S$-sites)

The parameters that correlated with the first PCA axis accounted for $64.5 \%$ of the variability, whereas those that correlated with the second axis explained $23.5 \%$ of the variability (Fig. 2).

The PCA measurements allowed classification of the physicochemical data into three different groups representing the three studied streams. The analysis confirmed that both $M_{1}$ and $M_{2}$ have very similar physiochemical parameters, while DR and $S$ differ from each other and from $M$ (Fig. 3).

On the basis of a Pearson linear correlation test (significance level of $P<0.01$ ) and a sample size of $n=30$, four of the nine studied physicochemical parameters were significantly correlated with morphometrical features of the Ulva thalli (Table 3).

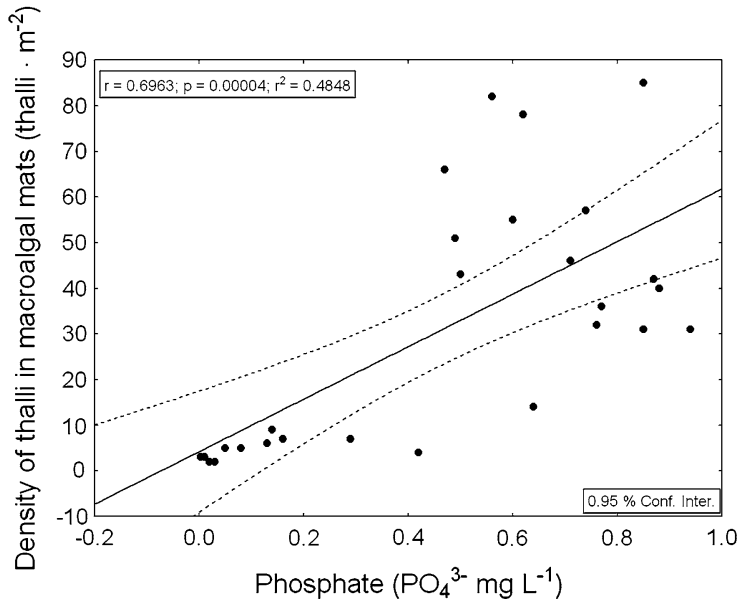

Fig. 4 Correlation between the density of Ulva thalli in macroalgal mats and different phosphate concentration in water habitat. Pearson coefficient of correlation: 0.70 ; $P<0.01 ; n=30$

Parameters such as water depth and concentrations of sodium chloride, nitrate and phosphate considerably affected development of the macroalgae thalli. The analysis showed that a concentration of phosphate was positively correlated with the density of thalli in macroalgal mats $\left(r=0.70 ; P<0.01 ; r^{2}=0.48\right.$; Fig. 4) and thalli length $(r=0.59 ; \quad P<0.01$; $\left.r^{2}=0.35\right)$.

Another important parameter that influenced the development of Ulva was sodium chloride. Sodium chloride was negatively correlated with the thalli

Table 3 Coefficients of linear Pearson's correlation $(r)$ and the coefficient of determination $\left(r^{2}\right)$ values among morphometric features of Ulva thalli with physicochemical factors

\begin{tabular}{|c|c|c|c|c|}
\hline Feature/parameter & $\begin{array}{l}\text { Depth } \\
\text { (cm) }\end{array}$ & $\begin{array}{l}\mathrm{NaCl} \\
\left(\mathrm{mg} \mathrm{L}^{-1}\right)\end{array}$ & $\begin{array}{l}\mathrm{P}^{-\mathrm{PO}_{4}} \\
\left(\mathrm{mg} \mathrm{L}^{-1}\right)\end{array}$ & $\begin{array}{l}\mathrm{N}-\mathrm{NO}_{3} \\
\left(\mathrm{mg} \mathrm{L}^{-1}\right)\end{array}$ \\
\hline \multirow[t]{2}{*}{ Density of thalli in $\mathrm{m}^{-2}$ of the mats } & $0.54 * *$ & $-0.68 * *$ & $0.70^{* *}$ & $0.56^{* *}$ \\
\hline & {$[0.29]$} & {$[0.47]$} & {$[0.48]$} & {$[0.31]$} \\
\hline \multirow{2}{*}{ Surface of the macroalgae mats } & $0.48 * *$ & $-0.55 * *$ & $0.52 * *$ & - \\
\hline & {$[0.23]$} & {$[0.30]$} & {$[0.27]$} & - \\
\hline \multirow[t]{2}{*}{ Average length of the thallus } & $0.38^{*}$ & $-0.64 * *$ & $0.59^{* *}$ & - \\
\hline & {$[0.14]$} & {$[0.40]$} & {$[0.35]$} & - \\
\hline \multirow[t]{2}{*}{ The percentage of the young thallus in $\mathrm{m}^{-2}$ of the mats } & $0.54 * *$ & $-0.40^{*}$ & - & - \\
\hline & {$[0.29]$} & {$[0.16]$} & - & - \\
\hline \multirow[t]{2}{*}{ The percentage of the mature thallus in $\mathrm{m}^{-2}$ of the mats } & $-0.54 * *$ & $0.40^{*}$ & - & - \\
\hline & {$[0.29]$} & {$[0.16]$} & - & - \\
\hline
\end{tabular}

$* P<0,05 ; * * P<0,01 ;\left[r^{2}\right] ; n=30$ 


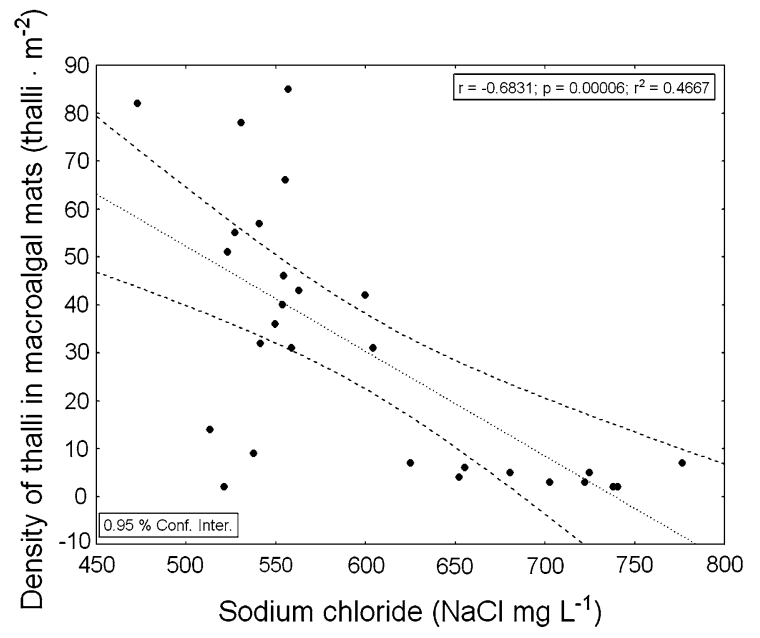

Fig. 5 Correlation between the density of Ulva thalli in macroalgal mats and different sodium chloride concentration in water habitat. Pearson coefficient of correlation: -0.68 ; $P<0.01 ; \mathrm{n}=30$

density (per $\left.\mathrm{m}^{2}\right)$ of mats $(r=-0.68 ; P<0.01$; $r^{2}=0.47$; Fig. 5) and the thalli length of the macroalgae $\left(r=-0.64 ; P<0.01 ; r^{2}=0.40\right)$. A high water concentration of sodium chloride inhibited thalli elongation and development and led to a decrease in the number of thalli in mats, especially in young plants $\left(r=-0.40 ; P<0.05 ; r^{2}=0.16\right)$. Increasing concentrations of sodium chloride that inhibited thalli development ultimately result in a reduction of the mat's surface development. Increasing water depth for all Ulva sites was positively correlated with the thalli density of mats and the percentage of young plants per mat $(r=0.54$; $\left.P<0.01 ; r^{2}=0.29\right)$. Increasing water depth also positively correlated with the mat's surface area ( $\left.r=0.48 ; P<0.01 ; r^{2}=0.23\right)$ and thalli length ( $\left.r=0.38 ; P<0.05 ; r^{2}=0.14\right)$. The water depth was also negatively correlated with the percentage of older algae per mat $(r=-0.54 ; \quad P<0.01$; $\left.r^{2}=0.29\right)$. Therefore, it is highly probable that deep water restricts the number of mature individuals in mats. Also, nitrate concentration, was positively correlated with thalli density of the mats $(r=0.54$; $\left.P<0.01 ; r^{2}=0.31\right)$. Therefore, a higher concentration of nitrate resulted in an increasing number of thalli forming the macroalgae mat. The analysis suggested that the density of Ulva thalli in mats was influenced by changes in sodium chloride and phosphate concentrations.

\section{Discussion}

Marine and freshwater Ulva species

The bloom development of Ulva species is uncommon in inland waters. As a marine species Ulva typically has a cosmopolitan range and appear only occasionally in inland freshwater ecosystems. They occur in ecosystems with elevated concentrations of chlorides and biogenic nutrients. In Poland, Ulva species have been observed in inland salt waters (Raciborski 1910; Namysłowski 1927), salt marshes (Piotrowska 1961; Wilkon-Michalska 1963) and peat pits (Pliński 1971, 1973a, 1973b). In those ecosystems, high concentrations of chlorides are natural, and the conditions are similar to those of littoral seawaters. These conditions have contributed to the permanent habitation of Ulva intestinalis in the mineral spring area of Ciechocinek since as early as the 19th century (Göppert and Cohn 1850; Kozłowski 1890) and later in other regions of Poland where salt waters are present (Torka 1910; Liebetanz 1925). However, Ulva species were also observed in freshwater systems, which are not naturally supplied with mineral waters possessing high sodium chloride concentrations. A dozen or so of these macroalgae sites have been found in lakes (Torka 1910; Pliński 1973a; Kowalski 1975; Dąmbska 1976; Messyasz 2009), fishponds (Marczek 1954; Piotrowska 1961; Kowalski 1975; Sitkowska 1999), rivers (Wysocka 1952; Kowalski 1975; Endler et al. 2006), canals and streams (Liebetanz 1925; Kowalski 1975; Messyasz and Rybak 2009).

Studies investigating species of Ulva, typically have been observed in freshwater ecosystems where low concentrations of chlorides were recorded but have provided little information concerning the phylogeny of these macroalgae. The genetic analyses of Ulva species based on sequencing nuclear-encoded 18S rDNA have identified relationships among Ulva populations in different ecosystems. Examinations of two populations of Ulva in freshwater ecosystems (river and stream) on Ryukyu island (Japan) resulted in identifying a new species (Ulva limnetica Ichihara and Shimada, sp. nov; Ichihara et. al. 2009). Subsequently, Mareš (2009) phylogenetically tested 20 populations of Ulva from freshwater ecosystems (fishpond, stream, water tank and river alluvium) in the Czech Republic. The author demonstrated that all collected freshwater specimens of Ulva in the Czech 
Republic clearly belong to the species $U$. flexuosa, a well-known euryhalinic and common saltwater taxa. Further research on the phylogeny of Ulva populations present in freshwater ecosystems is necessary. However, these works require the comparison of many holotypes from countries where new populations of these species may be identified in freshwater ecosystems.

At present, there are over 50 sites identified as having these chlorophytes in Poland, and it is estimated that there are many more. However, it has not been confirmed whether the species recorded at these sites are still present. Well recognised and described sites have been reported by Pliński (1971, 1973a, b), who described Ulva species observed in Polish lakes. The fragmented knowledge of the inland distribution of these species occurs, first, because there is a lack of sites where Ulva can survive and, secondly, not recognising these macroalgae in freshwater ecosystems. Few publications thoroughly discuss the circumstances and reasons for the occurrence of Ulva in fresh waters (Pliński 1971, 1973a, b; Kowalski 1975; Sitkowska 1999). In most cases, information about the occurrence of these chlorophyte thalli in a given ecosystem has been restricted lacking species identification and the site description during other limnological studies (Liebetanz 1925; Piotrowska 1961; Dąmbska 1976). Another important phenomenon is the occurrence of Ulva species in inland waters that are anthropogenically contaminated with sodium chloride (Messyasz 2009; Messyasz and Rybak 2009). Such contamination can reach small rivers and lakes in the form of rainwater runoff that flows mostly from city roads and motorways. This type of contamination occurs in the three streams in this study.

\section{Macroalgae mats}

Massive blooms of various Ulva species in seawater are known to exist as free-floating individual plants or as aggregations of thalli forming characteristic algal mats (Leskinen et al. 2004; Pregnall 1983; Pregnall and Rudy 1985; Malta et al. 1999; Bäck et al. 2000; Romano et al. 2003). The ability to form such aggregations seems to belong not only to individual species but also to the whole Ulva genus. However, it is generally accepted that microalgal mats are more common in estuaries and contaminated coastal seawaters (Bäck et al. 2000; Blomster et al. 2000, 2002). In the inland waters of Poland, large mats with surface areas up to $12 \mathrm{~m}^{2}$ formed by Ulva compressa and Ulva intestinalis have been found, among others, in Laskownickie Lake (Central Poland; Messyasz 2009). The mats of Ulva in the studied streams were much smaller (up to $4 \mathrm{~m}^{2}$ ) and associated with the small streambed, shallow water and less water depth as factors influencing the size of the algal mats. M with the deepest water $(89 \mathrm{~cm})$ and the largest mats also had the greatest number of thalli. In the other two streams, the mats were small (DR) or appeared rarely and included only a few plants $(S)$. A greater water depth at the analysed sites is associated not only with a larger mat surface but also with higher thalli density of mats and thalli length.

Mats formed by Ulva species in a sea littoral zone may achieve a considerable biomass. In Finland, coastal water mats of $U$. intestinalis covering an area of $3.7 \mathrm{~km}^{2}$ have yielded a biomass of 32 tons since 1997 and 97 tons since 1993 (Bäck et al. 2000). U. intestinalis is currently a dominant Ulva species in most Scandinavian coastal waters and in Poland (Haroon et al. 1999; Pliński and Jóźwiak 2004). In the Polish Baltic Sea, the number of $U$. compressa has decreased in favour of $U$. intestinalis (Pliński and Jóźwiak 2004). Bonsdorff et al. (1997) report multispecies mats are disappearing, whereas mono-species, e.g., $U$. intestinalis, is generally a very stable population for a few years. In the freshwater ecosystems studied here, Ulva populations also demonstrated continued annual development (personal observation from 2004), and they grow to a size similar to macroalgae patches.

\section{Thalli types}

Freshwater forms of Ulva may have two types of thalli: (1) thalli characteristic of young plants that have an intestinally undulating structure and (2) thalli occurring in mature and senescing plants that have a characteristic curly bubbled structure (Messyasz and Rybak 2008a). The degree of mature thalli corrugation may be connected with crystals of calcium carbonate, sulphates and chlorides covering the thallus. Scanning electron microscope observations of Ulva thalli were carried out by us and that the surface is covered with large numbers of diatoms, both in between and on the calcium carbonate crystals. Thus, 
the shape of thalli in young and mature plants results not only from the ontogenetic cycle coded in the genotype but is also influenced by other biotic and abiotic environmental factors. These factors significantly affect the deformation of the thalli surface.

\section{Competition}

Ulva mats are in serious competition for space with other species including vascular plants (duckweed) and other filamentous algae (e.g. Cladophora and Oedogonium) living in littoral waters. The domination of duckweed species at the studied sites occurred after the macroalgae developmental optimum and during gradual senescence of the chlorophyte thalli. The prevalence of duckweed and Spirodela in the surface water was possible not only due to a very high reproduction rate of these species but also because of a gradual slowing of the elongation growth and lack of young thalli development in Ulva. Massive development of duckweed and Spirodela species at the freshwater sites reduces the amount of light reaching algal thalli in deeper water. This stress leads to a change in colour of the thalli to dark green, resulting from increased concentrations of photosynthetic pigments in the thallus cells. Such a colour change of marine Ulva species' thalli also depends on the increasing water depth at which they grow. Thalli sampled from deeper waters are darker than those that grow closer to the surface. Moreover, De Valera (1940) claims that this phenomena is caused by high concentrations of nutrients in marine water, therefore the change in pigmentation can be used as a contamination indicator. The last experimental ex situ examinations (Figueroa et al. 2009; Villares and Carballeira 2004) conducted on marine species of Ulva (U. intestinalis, U. rigida, U. lactuca) also confirmed that nutrient availability has an influence on the pigmentation of thalli and their photosyntheses ratio. Han et al. (2008) point out that high concentrations of heavy metals (e.g. copper) also influence the pigmentation of Ulva thalli. At present, no similar information is available for Ulva thalli from freshwater ecosystems.

Effects of chlorides and temperature

The occurrence of Ulva species in freshwater ecosystems in Poland is influenced by various environmental factors, and the most important of which are high concentrations of nutrients and chlorides that stimulate thalli development (Pliński 1971; Sitkowska 1999; Messyasz and Rybak 2008b). The effect of the above-mentioned parameters on thalli structure, manifested by branching or lack of branching, has been noticed in marine forms of $U$. compressa and $U$. intestinalis (Leskinen et al. 2004). At low chloride concentrations, the thalli of both species were highly furcated. Moreover, Leskinen et al. (2004) observed furcated thalli in $U$. compressa and non-furcated thalli in $U$. intestinalis on the coasts of Sweden, Norway and Denmark. However, in areas with salinity higher than 27 ppt non-furcated thalli of $U$. compressa and furcated thalli of $U$. intestinalis were present. Thus, it was concluded that the degree of thallus branching of $U$. intestinalis is connected with higher chloride concentrations more than for $U$. compressa. These observations were confirmed in laboratory experiments, where De Silva and Burrows (1973) proved that salinity significantly affects the branching ability of these species. The results of our studies suggest that the degree of branching of Ulva $s p$. thalli does not depend on sodium chloride concentration but is slightly positively correlated with water temperature $(r=0.38 ; P<0.05)$. Whether there is a stimulating effect of water temperature on thalli branching is unclear, and it is probable that the degree of branching is also due to other, as of yet unidentified, environmental factors.

Sites $M_{1}, M_{2}$, DR and $\mathrm{S}$ have received large loads of chlorides, especially in winter, from the motorway since 2003. During periods of low temperatures, the motorway operator uses sodium chloride (in solution and dry) and calcium chloride (only in solution) to keep the road free from ice (personal communication, Włodzimierz Matczak, assistant director of Motorway Operations). It is likely that the motorway system of pre-treating water results in a regular dosage of incoming chlorides to these streams. Comparative studies of sodium chloride concentration carried out in summer, autumn and winter (taking into consideration thawing and pre-thawing periods) showed constantly elevated levels of 528-613 $\mathrm{mg} \mathrm{L}^{-1}$ (January 12, air temp. $+6^{\circ} \mathrm{C}$ ) and 592-647 $\mathrm{mg} \mathrm{L}^{-1}$ (December 15, air temp. $-2^{\circ} \mathrm{C}$ ). Heavy rains do not considerably affect chloride dilution in these streams. High sodium chloride levels have a negative influence on the Ulva 
population, leading to reduced length and number of thalli and consequently decreasing the mat's surface area. The decline in these morphometric parameters is visible at sodium chloride concentration $>400$ $\mathrm{mg} \mathrm{L}^{-1}$. It was not determined what chloride concentration in freshwaters leads to thalli development or maintenance. This optimum level was impossible to define, as throughout the whole observation period the level of sodium chloride was high for all macroalgae sites. Nevertheless, sodium chloride is one of the most important factors affecting the development of Ulva in freshwater. Similarly, Messyasz (2009) notes that low chloride concentrations in Laskownickie Lake may be connected with faster thalli development in enriched waters. The distribution of Ulva (e.g. U. compressa) in the Baltic Sea is, in turn, much more dependent on salinity than originally assumed (Nielsen et al. 1995; Tolstoy and Willén 1997). In the work published by Leskinen et al. (2004) describing the distribution of $U$. compressa along the Norwegian, Swedish, Finnish and Danish coasts, this species was not observed in waters with a salinity below $15 \mathrm{ppt}$. It was then concluded that salinity is an important limiting factor of $U$. compressa distribution in the Baltic Sea. These conclusions were confirmed in experimental studies (Koemann and Van den Hoek 1982) that revealed that this alga does not grow in waters with low sodium chloride concentrations and that only a minimal level is necessary for its proper development. Taylor et al. (2001) also report that $U$. compressa has a wide tolerance range towards salt and grows in water of salinity ranging from 0 to 34 psu. When there is a low concentration of chlorides, the development of this species is restrained, and it is the most effective at salinity of 6 to 8 psu.

\section{Biogenic substances}

Phosphates are another essential chemical parameter influencing the development of Ulva in freshwaters. Phosphorus concentrations are strongly positively correlated with thalli density of mats, the mat's surface area and average length of thalli forming the mat $(r=0.70 ; r=0.52$ and $r=0.59$ for $P<0.01$, respectively). This finding was confirmed in laboratory studies that showed that $\mathrm{P}$ concentrations are positively correlated with the photosynthesis rate of $U$. compressa and consequently with the growth of its thalli (Villares and Carballeira 2004). The highest biomass growth rate of the chlorophytes occurred at phosphate concentrations of $20-30 \mathrm{mmol} \mathrm{m}^{-3}$ (Taylor et al. 2001).

Most studies regarding the ecology and distribution of marine Ulva species indicate that these algae occur in areas with high concentrations of nitrogen compounds, mostly of nitrate and ammonium. Furthermore, the appearance of large algal mats is a sign of elevated levels of these compounds in the littoral regions of marine habitats (Sfriso et al. 1987; Raffaelli et al. 1989; Fletcher 1992; 1996; Bonsdorff et al. 1997; Sfriso and Marconimi 1997; 1999; Sfriso et al. 2001; Martins et al. 2001). Our studies show that increasing concentrations of nitrates in freshwater lead to greater numbers of thalli in the microalgae mats of Ulva $(r=0.56 ; P<0.01)$, whereas the influence of ammonium on the development of this species is not statistically significant.

\section{Summary}

There is an important relationship between the morphological features of Ulva and the salinity and nutrient concentrations in these freshwater habitats. In addition, high concentrations of chlorides in the water were unfavourable for development of the Ulva thalli. Statistical analyses showed that the most essential physical factor positively correlated with development of Ulva mats was water depth.

In order to better understand the ecology and distribution of Ulva species in inland ecosystems, it is necessary to intensify the studies at new freshwater sites where these chlorophytes are located. It is probable that large macroalgal mats in freshwaters can have a considerable influence on both the water and benthic organisms living under these mats, as shown for marine ecosystems. Therefore, it is necessary to further examine reasons for the appearance of bloomforming mats of Ulva in freshwater ecosystems.

Acknowledgments We are grateful to Professor Lubomira Burchardt for her helpful suggestions and critical comments on the manuscript. We also thank Dr. Maciej Gąbka for assisting in the statistical analyses. This research was financially supported by the Polish Ministry of Science and Higher Education (grant No. NN304 013437). We also thank the anonymous reviewers of this paper for the valuable, critical and helpful comments on the manuscript. 
Open Access This article is distributed under the terms of the Creative Commons Attribution Noncommercial License which permits any noncommercial use, distribution, and reproduction in any medium, provided the original author(s) and source are credited.

\section{References}

Bäck S, Lehvo A, Blomster J (2000) Mass occurrence of unattached Enteromorpha intestinalis on the Finnish Baltic Sea coast. Ann Bot Fennici 37:155-161

Bliding C (1963) A critical survey of european taxa in Ulvales. Part 1. Casosiphonia, Blidingia, Enteromorpha. Opera Bot 8(3):1-160

Bliding C (1968) A critical survey of european taxa in Ulvales. Part 2. Ulva, Ulvaria, Monostoma, Kornmannia. Bot Not 121:534-629

Blomster J, Hoey EM, Maggs CA, Stanhope MJ (2000) Species-specific oligonucleotide probes for macroalgae: molecular discrimination of two marine fouling species of Enteromorpha (Ulvophyceae). Mol Ecol 2:177-185. doi: 10.1046/j.1365-294x.2000.00850.x

Blomster J, Back S, Fewer DP, Kiirikki M, Lehvo A, Maggs CA, Stanhope MJ (2002) Novel morphology in Enteromorpha (Ulvophycae) forming green tides. Amer J Bot 89:1756-1763. doi:10.3732/ajb.89.11.1756

Bonsdorff E, Blomqvist EM, Mattila J, Norkko A (1997) Coastal eutrophication: cause, consequences and perspectives in the archipelago areas of the northern Baltic Sea. Estuar Coast Shelf Sci 44:63-72. doi:10.1016/S02 72-7714(97)80008-X

Callow ME, Callow JA, Pickett Heaps JD, Wetherbee R (1997) Primary adhesion of Enteromorpha (Chlorophyta, Ulvales) propagules: quantitative settlement studies and video microscopy. J Phycol 33:938-947

Dąmbska I (1976) Materials of the study of peryphiton of the Konin Lakes. Seria Biol Uniw A Mickiewicz in Poznań 6:85-90

De Silva MW, Burrows EM (1973) An experimental assessment of the status of the species Enteromorpha intestinalis (L.) Link and Enteromorpha compressa (L.) Grev. J Marine Biol Assoc UK 53:895-904. doi: 10.1017/S002 5315400022554

De Valera M (1940) Note on the difference in growth of Enteromorpha species in various culture media. $\mathrm{Kgl}$ Fysiogr Sallsk Lund Forhandl 10(5):52-58

Endler Z, Goździejewska A, Jaworska B, Grzybowski M (2006) Impact of small hydropower station on Plankton organisms in river water. Acta Sci Pol Formatio Circumiectus 5(2):121-134

Figueroa FL, Israel A, Neori A, Martinez B, Malta EJ, Put Ang J, Inken S, Marquardt R, Korbee N (2009) Effects of nutrient supply on photosynthesis and pigmentation in Ulva lactuca (Chlorophyta): responses to short-term stress. Aquat Biol 7:173-183. doi:10.3354/ab00187

Fish JD, Fish S (1989) A student's guide to seashore. Uniwin Hyman Ltd. London 11:35-36. doi:10.1017/S00253154 00034391
Fletcher RL (1992) The "green tide" problem. In: Schramm W, Nienhuis P (eds) Ecological studies, marine benthic vegetation. EEC, Brussels, pp 29-33. doi: 10.1017/S0025 315400034111

Fletcher RL (1996) The occurrence of "green tide" problem. In: Schramm W, Nienhuis P (eds) Ecological studies, marine benthic vegetation. EEC, Brussels, pp 7-43. doi: 10.1017/S0025315400034111

Gabrielson PW, Widdowson TB, Lindstrom SC, Hawkes MJ, Scagel RF (2000) Keys to the benthic marine algae and seagrasses of British Columbia, southeast Alaska, Washington and Oregon. Department of Botany, University of British Columbia, Vancouver. doi: 10.1046/j.1529-8817. 2002.38101.x

Göppert HR, Cohn F (1850) Ueber die Algen Schlesiens. Übers Arbeiten Veränd Schles Ges Vaterl Cultur 1:93-95

Graham LE, Wilcox LW (2000) Algae. Prentice-Hall, Upper Saddle River, p 253

Han T, Kang SH, Park JS, Lee HK, Brown MT (2008) Physiological responses of Ulva pertusa and U. armoricana to copper exposure. Aquatic Toxicol 86:176-184. doi: 10.1016/j.aquatox.2007.10.016

Haroon MA, Szaniawska A, Pliński M (1999) The distribution, species compositions and abundance of Enteromorpha spp. in the Gulf of Gdańsk. Oceanol Stud 28(1-2): 31-39

Hayden HS, Blomster J, Maggs CH, Silva P, Stanhope M, Waaland R (2003) Linnaeus was right all along: Ulva and Enteromorpha are not distinct genera. Eur J Phycol 38:277-294. doi:10.1080/1364253031000136321

Ichihara K, Arai S, Uchimura M, Fay EJ, Ebata H, Hiraoka M, Shimada S (2009) New species of freshwater Ulva, Ulva limnetica (Ulvales, Ulvophyceae) from the Ryukyu Islands, Japan. Phycol Res 57:94-103. doi:10.1111/j. 1440-1835.2009.00525.x

Kirchhoff A, Pflugmacher S (2002) Comparison of the detoxication capacity of limnic and marine form of the green algae Enteromorpha compressa. Marine Envirn Res 50:60-81. doi:10.1016/S0141-1136(00)00251-8

Koemann R, Van den Hoek C (1982) The taxonomy of Enteromorpha link, 1820 (Chlorophyceae) in The Netherlands. I. The section Enteromorpha. Arch Hydrobiol Suppl 63:279-330

Kowalski W (1975) Occurrence of the species of a Marine Green Alga Enteromorpha Link (1982) in the Szczecin Pomerania inland waters. Fragm Flor Geobot Ser Polonica 21:527-536

Kozłowski W (1890) Introduction to the seaweed flora from the vicinity of the Ciechocinek. Pam Fizjogr 10:1-3

Lee RE (1999) Phycology, III. Cambrige University Press, Cambrige, p 614

Leghari SM, Jafri SIH, Mahr MA, Lashari KH, Ali SS, Jahangir TM, Khuahawar MY (2000) Limnological Study of Sonharo, Mehro Pateji and Cholari Lakes of District Badin, Sindh Pakistan. Pakistan J Biol Sci 3(11):19041909

Leskinen E, Alström-Rapaport C, Pamilo P (2004) Phytogeographical structure, distribution and genetic variation of the green algae Ulva intestinalis and $U$. compressa (Chlorophyta) in the Baltic Sea area. Mol Ecol 13: 2257-2265. doi:10.1111/j.1365-294X.2004.02219.x 
Liebetanz B (1925) Hydrobiologische Studien an Kujawischen Brackwässern. Bull Intern Acad Polon Sci Lettres Sci Math Nat Ser B Sci Mat, pp 116

Malta EJ, Draisma SGA, Kamermans P (1999) Free floating Ulva in the southwest Netherlands: species or morphotypes? A morphological, molecular and ecological comparison. Eur J Phycol 34:443-454. doi:10.1080/095414 49910001718801

Marczek E (1954) A New locality of Enteromorpha intestinalis (L.) Link Kützig [(L.) Greville] and Enteromorpha tubulosa J. G. Agardh. Fragm Flor Geobot Ser Polonica 2: $105-111$

Mareš J (2009) Combined morphological and molecular approach to the assessment of Ulva (Chlorophyta, Ulvophyceae) in the Czech Republic. Master thesis. University of South Bohemia, Faculty of Science, Department of Botany

Martins I, Pardal MA, Lillebo AI, Flindt MR, Marques JC (2001) Hydrodynamics as a major factor controlling the occurrence of green macroalgal blooms in a eutrophic estuary: a case study on the influence of precipitation and river management. Estuar Coast Shelf Sci 52:165-177. doi:10.1006/ecss.2000.0708

McAvoy KM, Klug JL (2005) Positive and negative effects of riverine input on the estuarine green alga $U$. intestinalis (syn. E. intestinalis) (Linneus). Hydrobiologia 545:1-9. doi:10.1007/s10750-005-1923-5

Messyasz B (2009) Enteromorpha (Chlorophyta) populations in River Nielba and Lake Laskownickie. Oceanol Hydrobiol Stud 38(1):1-9

Messyasz B, Rybak A (2008a) New inland localities of saltlike green alga Enteromorpha compressa (L.) Ness in Poland. Badania Fizjograficzne nad Polską Zachodnią, Seria B-Botanika 57:77-88

Messyasz B, Rybak A (2008b) Occurrence of Enteromorpha compressa [syn. Ulva compressa (L.)] (Chlorophyta) in the Wielkopolska Region. Fragm Flor Geobot. Ser Polonica 15(1):17-19

Messyasz B, Rybak A (2009) The distribution of green algae species from the Ulva genera [syn. Enteromorpha; Chlorophyta] in Polish inland waters. Oceanol Hydrobiol Stud 38(1):121-138. doi: 10.2478/v10009-009-0001-0

Namysłowski B (1927) Hydrobiology research. Prace Komis Mat Przyrod Poz Tow Przyj Nauk Ser B Nauk Biolog $1: 1-13$

Nielsen R, Kristiansen A, Mathiesen L, Mathiesen H (1995) Distributional index of the benthic macroalgae of the Baltic Sea area. Acta Botanica Fennica 155:1-51

Piotrowska H (1961) Halophytes near the Kołobrzeg. Chrońmy Przyr Ojcz 17(4):24-28

Pliński M (1971) The species of Enteromorpha (Link) Agardh genus from the area of salt pans near Łęczyca. Zesz Nauk UŁ Biol 41:159-169

Pliński M (1973a) The algae of salt marshes near Łęczyca, Central Poland. Monogr Bot 39:3-88

Pliński M (1973b) A new locality of Enteromorpha intestinalis (L.) Greville in Poland. Fragm Flor Geobot Ser Polonica 19(1):135-137

Pliński M, Florczyk I (1984) Analysis of the composition and vertical distribution of the macroalgae in Western part of the Gulf of Gdańsk in 1979 and 1980. Oceanologia 19: 101-115

Pliński M, Jóźwiak T (2004) The distribution of water vegetation on the Polish coast of the Baltic sea in 1996-2000. Oceanol Hydrobiol Stud 32(2):29-40

Pliński M, Manasterska M, Florczyk I (1982) The preliminary ecological characteristic of genus Enteromorpha (Link) in the Bay of Gdańsk. Zesz Nauk. Wydz. Biol. Nauk Ziemi, Oceanografia, Uniw Gdańsk 9(1):65-80

Pregnall AM (1983) Release of dissolved organic carbon from the estuarine intertidal macroalga Enteromorpha prolifera. Mar Biol 73:37-42. doi:10.1007/BF00396283

Pregnall AM, Rudy PP (1985) Contribution of green macroalgal mats (Enteromorpha ssp.) to seasonal production in an estuary. Mar Ecol Prog Ser 24:167-176

Raciborski M (1910) Phycotheca polonica. Part 1, Kosmos. 35:80-89, 1001-1006

Raffaelli D, Hull S, Milne H (1989) Long-term changes in nutrients, weed mats and shorebirds in an estuarine system. Cah Biol Mar 30:259-270

Reinke DC (1981) Enteromorpha, a Marine Alga in Kansas. Trans Kansas Academy Sci 84(4):228-230. doi:10.2307/ 3628281

Romano C, Windows J, Brinsley MD, Staff FJ (2003) Impact of Enteromorpha intestinalis mats on near-bed currents and sediment dynamics: flume studies. Mar Ecol Prog Ser 256:63-74. doi:10.3354/meps 256063

Sfriso A, Marconimi A (1997) Macrophyte production in a shallow coastal lagoon. Part I. Coupling with chemicophysical parameters and nutrient concentrations in waters. Mar Environ Res 44:351-375. doi:10.1016/S0141-113 6(97)00012-3

Sfriso A, Marconimi A (1999) Macrophyte production in a shallow coastal lagoon. Part II. Coupling with sediment, SPM and tissue carbon, nitrogen and phosphorus concentrations. Mar Environ Res 47:285-309. doi:10.1016/ S0141-1136(98)00122-6

Sfriso A, Marcomini A, Pavoni B (1987) Relationships between macroalgae biomass and nutrient concentrations in the hypertrophic area of the Venice lagoon. Mar Env Res 22:297-312. doi:10.1016/0141-1136(87)90005-5

Sfriso A, Birkemeyer T, Ghetti PF (2001) Benthic macrofauna changes in areas of Venice lagoon populated by seagrasses or seaweeds. Mar Environ Res 52:323-349. doi: 10.1016/S0141-1136(01)00089-7

Sitkowska M (1999) Two new localities from Enteromorpha flexuosa subsp. pilifera (Chlorophyta) in Poland. Fragm Flor Geobot Ser Polonica 6:301-304

Starmach K (1972) Green alga. In: Starmach K (ed) Freshwater flora of Poland. PWN, Warszawa-Kraków, p 163

Taft CE (1964) The occurrence of Monostoma and Enteromorpha in Ohio. Ohio J Sci 64(4):272-273

Taylor R, Fletcher RL, Raven JA (2001) Preliminary studies on the growth of selected "green tide" algae in laboratory culture: effects of irradiance, temperature, salinity and nutrients on growth rate. Bot Mar 44:327-336. doi: 10.1515/BOT.2001.042

Tolstoy A, Willén T (1997) Preliminary checklist of macroalgae in Sweden. Artdatabanken. Agricultural University of Sweden, Uppsala, pp 6-10 
Torka V (1910) Zur Erforschung Posener Algen. Zeitschr d Naturw Abt 16:179-187

Villares R, Carballeira A (2004) Nutrient limitation in Macroalgae (Ulva and Enteromorpha) from the Rias Baixas (NW Spain). Mar Ecol 25(3):225-243. doi:10.1111/j. 1439-0485.2004.00027.x

Wallentinus I (1979) Environmental influences on benthic macrovegetation in the Trosa-Askö area, northern Baltic proper. II. The ecology of macroalgae and submersed phanerogams. Contributions to the Askö Laboratory. University of Stockholm, pp 1-210

Whitton BA, Dalpra M (1968) Floristic changes in the River Tees. Hydrobiologia 32:545-550. doi:10.1007/BF0015 5407
Wilkoń-Michalska J (1963) The halophytes from Kujawy. Stud Soc Sc Tor Sect D 7(1):1-121

Williams CH (1993) Processes of Aquatic Weed Invasions: the New Zealand example. J Aquat Plant Manage 31:17-23

Wysocka H (1952) The Marine alga in the Wisła River near Warsaw. Gazeta Obserwatora PIHM 5(4):7-10

Żbikowski R, Szafer P, Latała A (2005) Distribution and relationships between selected chemical elements in green alga Enteromorpha sp. from the southern Baltic. Envir Poll 3:435-448. doi:10.1016/j.envpol.2005.12.007 